\title{
ANALISIS KADAR POLIFENOL DAN AKTIVITAS ANTIOKSIDAN YANG TERDAPAT PADA EKSTRAK BUAH : STUDI KEPUSTAKAAN
}

\author{
[Polyphenols Levels and Antioxidant Activity Analysis on Fruits Extract: A Review] \\ Elma Febriana*), Tamrin, RH. Fitri Faradillah \\ Jurusan Ilmu dan Teknologi Pangan, Fakultas Pertanian, Universitas Halu Oleo, Kendari \\ Email: elmafebriana0101@gmail.com; (Telp: 082291786673) \\ Diterima Tanggal 26 juni 2019. \\ Disetujui Tanggal 04 Juli 2019
}

\begin{abstract}
Polyphenols are one of the largest categories of phytochemicals and are the most widely distributed among various types of plants and fruits. Polyphenols can also inhibit, prevent, and reduce oxidation by free radicals, which are good for health. Analysis of polyphenol content starts from the sample preparation process which includes the extraction of solid and liquid samples. The types of solvents commonly used for extraction are ethanol, methanol, and acetone. Furthermore, the analysis of polyphenol levels uses the Folin-Ciocalteau analysis method. The results of the review show that ripe bisbul fruit extract (Diospyros blancoi A. DC.) which was extracted using ethanol as a solvent had the highest polyphenol content and yield of several fruit extracts reported in this review. Meanwhile, the extract of green grapes (Vitis vinifera Linn. Var. Chinsiang) which was extracted using ethanol as a solvent had the lowest levels and yields of polyphenols. The highest antioxidant activity was shown by samples of red dragon fruit extract (Hylocereus polyrhizus (f.a.c weber) britton \& rose). Meanwhile, the lowest antioxidant activity was shown by samples of Watermelon (Citrullus lanatus) fruit extract.
\end{abstract}

Keywords: Pholyphenol, Extracts, Solvents, Folin Ciocalteau

\section{ABSTRAK}

Polifenol adalah salah satu kategori terbesar dari fitokimia yang paling banyak penyebarannya diantara berbagai jenis tanaman dan buah-buahan. Polifenol juga dapat menghambat, mencegah, mengurangi oksidasi oleh radikal bebas sehingga baik untuk kesehatan. Analisis kadar polifenol dimulai dari proses preparasi sampel yang meliputi ekstrasi sampel padat dan ekstraksi sampel cair. Jenis pelarut yang umum digunakan saat pengekstrakan yaitu etanol, metanol, dan aseton. Selanjutnya analisis kadar polifenol menggunakan metode analisis folin ciocalteau. Hasil review menunjukkan Ekstrak buah bisbul matang (Diospyros blancoi A. DC.) yang diekstrak menggunakan pelarut etanol memiliki kadar dan rendemen polifenol yang tertinggi dari beberapa ekstrak buah yang dilaporkan dalam review ini. Sedangkan ekstrak buah anggur hijau (Vitis vinifera Linn. Var. Chinsiang) yang diekstrak menggunakan pelarut etanol memiliki kadar dan rendemen polifenol yang terendah. Aktivitas antioksidan yang tertinggi ditunjukkan oleh sampel ekstrak buah naga Merah (Hylocereus polyrhizus (f.a.c weber) britton \& rose) dibandingkan sampel lain dalam review ini. Sedangkan aktivitas antioksidan yang terendah ditunjukkan oleh sampel ekstrak buah Semangka (Citrullus lanatus) dibandingkan sampel lain dalam review ini.

Kata kunci: Polifenol, ekstraksi, pelarut, folin ciocalteau 


\section{PENDAHULUAN}

Keanekaragaman hayati Indonesia sangat berpotensi dalam penemuan senyawa baru flavonoid, polifenol, dan sebagai antioksidan. Penelitian menunjukkan bahwa beberapa tumbuhan terbukti bermanfaat melindungi tubuh manusia dari bahaya radikal bebas, karena adanya antioksidan yang terdapat dalam tumbuhan tersebut. Secara alami, tumbuhan yang mengandung antioksidan tersebar pada berbagai bagian tumbuhan seperti akar, batang, kulit, ranting, daun, buah, bunga dan biji (Kuncahyo dan Sunardi, 2007).

Senyawa fenol alami yang bersifat antioksidan dapat diklasifikasikan dalam 2 (dua) kelompok, yaitu kelompok lipofilik dan hidrofilik (diantaranya senyawa fenol). Aktivitas antioksidan dari senyawa fenol terbentuk karena kemampuan senyawa fenol membentuk ion fenoksida yang dapat memberikan satu elektronnya kepada radikal bebas. Gambaran pada umumnya yaitu, antioksidan senyawa fenol $(\mathrm{PhH})$ dapat bereaksi dengan radikal bebas (ROO•) membentuk $\mathrm{ROOH}$ dan sebuah senyawa fenol radikal $(\mathrm{Ph} \bullet$ yang relatif tidak reaktif. Selanjutnya, senyawa fenol radikal $(\mathrm{Ph} \bullet)$ dapat bereaksi kembali dengan radikal bebas (ROO•) membentuk senyawa yang bersifat tidak radikal (Dhianawaty, 2013).

Beberapa senyawa dari polifenol mempunyai aktivitas anthipertensi. Beberapa penelitian juga memperlihatkan bahwa flavonoid dan tanin yang umumnya terdapat dalam buah-buahan, sayur-sayuran, serta minuman mampu menghambat nicotinamida adenine dinucleotida phosphate (NADPH) oksidase melalui penghambatan ACE, peningkatan eNOS-spesifik, dan juga mengubah ekspresi siklooksigenase-2 (COX-2) (Baradaran et al., 2014). Flavonoid dan tanin menghambat aktivitas ACE, yang penting dalam pengaturan tekanan darah arteri. Aktivitas senyawa fenol berasal dari jumlah gugus hidroksil pada cincin benzena. Penelitian docking menunjukkan bahwa asam fenolat dan flavonoid menghambat ACE melalui interaksi dengan ion zink dan interaksi ini distabilkan oleh interaksi lain dengan asam amino pada sisi aktif (Mensah et al., 2010).

Senyawa fenol merupakan kelas utama antioksidan yang berada dalam tumbuh-tumbuhan. Kandungan senyawa fenolat banyak diketahui sebagai penghancur radikal bebas dan pada umumnya kandungan senyawa fenolat berkorelasi positif terhadap aktivitas antioksidan (Marinova dan Batcharov, 2011). Hasil penelitian Miller et al., (2006), Gu et al., (2006), Redovnikovic et al., (2009) dan Chin et al.. (2013) menyatakan kapasitas antioksidan pada biji kakao maupun berbagai produk cokelat mempunyai korelasi positif dengan jumlah total polifenol maupun gugus fenol flavan-3 ol dan proanthocyanidin yang dikandungnya. Selanjutnya pada penelitian Weecharangsan et 
al., (2013) menyatakan ekstrak etanol kulit buah manggis diketahui mengandung alkaloid, glikosida, steroid, flavonoid, polifenol, dan tanin yang bertanggung jawab dalam memberikan aktivitas farmakologi.

\section{Preparasi Sampel}

Sebelum dilakukan analisis polifenol, sampel terlebih dahulu dilakukan preparasi tahap awal yakni persiapan bahan yang akan diuji kadar polifenolnya.

\section{a. Ekstraksi Sampel Padat (Shimamura, 2011)}

Sampel dihaluskan menggunakan blender hingga berbentuk bubuk dan diayak dengan menggunakan ayakan. Kemudian ditimbang dan dimasukan ke dalam erlenmayer. Selanjutnya ditambahkan dengan absolute etanol dan dikocok menggunakan alat shaker selama 6 jam. Kemudian disaring dengan menggunakan kertas saring untuk memisahkan endapan dan filtratnya. Kemudian endapannya ditambahkan kembali dengan absolute etanol dan dikocok kembali menggunakan alat shaker selama 6 jam. Setelah 6 jam kemudian disaring kembali menggunakan kertas saring untuk memisahkan endapan dan filtratnya. Selanjutnya filtrat yang diperoleh dari dua kali ekstraksi siap untuk dilakalukan analisis polifenol.

\section{b. Ekstraksi Sampel Cair (Arifulloh et al., 2016)}

Bahan ekstraksi yaitu sampel cair dihaluskan menggunakan alat blender. Kemudian dimasukkan ke dalam gelas beaker lalu ditambahkan pelarut dan diaduk selama 5 menit. Setelah itu, campuran disaring kemudian endapan dengan kuantitas yang sama dimasukkan ke dalam erlenmeyer dan ditutup kemudian dilapisi dengan kertas karbon pada bagian luar. Kemudian ditambahkan pelarut selanjutnya dikocok menggunakan alat shaker dengan kecepatan $150 \mathrm{rpm}$ selama 30 menit. Campuran dipindahkan ke dalam corong pisah, ditambahkan $10 \mathrm{~mL}$ aquades, selanjutnya dikocok kembali kemudian didiamkan sampai terbentuk dua fase. Lapisan atas (non polar) diambil dan diuapkan menggunakan rotary rotavapor. Ekstrak pekat hasil rotary evaporator dimasukkan ke dalam botol kaca dan diukur volumenya.

\section{Jenis Pelarut yang Sering Digunakan Pada Ekstraksi Analisis Kadar Polifenol \\ a. Etanol (Supriyanto, 2010)}

Etanol atau etil alkohol, $\mathrm{C}_{2} \mathrm{H}_{5} \mathrm{OH}$, merupakan cairan yang tidak berwarna, larut dalam air, eter, aseton, benzen dan semua pelarut organik, serta memiliki bau khas alkohol. Etanol mempunyai sifat tidak berwarna, mudah menguap, mudah larut dalam air, berat molekul 46,1 , titik didihnya $78,3^{\circ} \mathrm{C}$, membeku pada suhu $-117,3^{\circ} \mathrm{C}$, kerapatannya 0,789 pada suhu $20^{\circ} \mathrm{C}$, nilai kalor $7077 \mathrm{kal} / \mathrm{gram}$, panas latent penguapan $204 \mathrm{kal} / \mathrm{gram}$ dan mempunyai angka oktan 91-105. 


\section{b. Metanol (Yuan et al., 2011)}

Metanol adalah senyawa alkohol dengan 1 rantai karbon. Rumus Kimia $\mathrm{CH}_{3} \mathrm{OH}$, dengan berat molekul 32 . Titik didih $640-65^{\circ} \mathrm{C}$ (tergantung kemurnian), dan berat jenis 0,7920-0,7930 (juga tergantung kemurnian). Secara fisik metanol merupakan cairan bening, berbau seperti alkohol, dapat bercampur dengan air, etanol, chloroform dalam perbandingan berapapun, hygroskopis, mudah menguap dan mudah terbakar dengan api yang berwarna biru.

\section{c. Aseton (Wade, 2006)}

Rumus molekul aseton adalah $\mathrm{CH}_{3} \mathrm{COCH}_{3}$ dengan berat molekul $50,1 \mathrm{~kg} / \mathrm{mol}$ dititik leleh $-94,6{ }^{\circ} \mathrm{C}$. Aseton merupakan keton yang paling sederhana, digunakan sebagai pelarut polar dalam kebanyakan reaksi organik. Aseton dikenal juga sebagai dimetil keton, 2-propanon, atau propan-2-on. Aseton adalah senyawa berbentuk cairan yang tidak berwarna dan mudah terbakar, digunakan untuk membuat plastik, serat, obat-obatan, dan senyawa-senyawa kimia lainnya. Selain dimanufaktur secara industri, aseton juga dapat ditemukan secara alami, termasuk pada tubuh manusia dalam kandungan kecil. Aseton memiliki gugus karbonil yang mempunyai ikatan rangkap dua karbon. Umumnya atom hidrogen yang terikat pada atom karbon sangat stabil dan sangat sukar diputuskan. Namun lain halnya dengan atom hidrogen yang berada pada karbon (C) di samping gugus karbonil yang disebut atom hidrogen alfa (a).

\section{Metode Analisis (Huang et al., 2005)}

\section{a. Metode FolinCiocalteau}

Sebanyak $10 \mathrm{mg}$ ekstrak dilarutkan dalam $25 \mathrm{~mL}$ etanol $96 \% .2 \mathrm{~mL}$ larutan tersebut dimasukkan ke dalam tabung reaksi lalu ditambahkan $5 \mathrm{~mL}$ aquades, dan $0,5 \mathrm{~mL}$ pereaksi FolinCiocalteau $50 \%$ lalu dikocok dengan vorteks. Campuran tersebut diinkubasi pada suhu ruang selama 5 menit lalu ditambahkan 1 $\mathrm{mL} \mathrm{Na}_{2} \mathrm{CO}_{3} 5 \%$, diaduk, kemudian diinkubasi pada suhu ruang selama 60 menit. Absorban larutan diukur menggunakan spektrofotometer pada panjang gelombang $725 \mathrm{~nm}$. Standar yang digunakan yaitu asam galat dengan berbagai konsentrasi $(10 ; 30 ; 50$; dan $70 \mu \mathrm{g} / \mathrm{ml})$. Penetapan kadar fenol menggunakan pereaksi FolinCiocalteau berdasarkan kekuatan mereduksi dari gugus hidroksil fenol.

\section{b. Metode DPPH (Shimamura, 2014)}

Prosedur pengujian DPPH, pertama-tama larutan DPPH disiapkan dengan cara menimbang $4 \mathrm{mg}$ DPPH dan dilarutkan DPPH di dalam labu takar $100 \mathrm{~mL}$ dengan menggunakan etanol. Selanjutnya dibungkus labu takar dengan aluminium foil. Disimpan larutan DPPH selama 2 jam di tempat gelap kemudian diukur absorbansi larutan 
DPPH dengan menggunakan alat spektrofotometer pada panjang gelombang $517 \mathrm{~nm}$. Jika absorbansi lebih dari 1.05, diencerkan larutan dengan menambahkan etanol hingga absorbansi kurang dari 1,05. Digunakan larutan DPPH untuk pengujian pada hari yang sama. Larutan tidak boleh disimpan lebih dari 1 hari.

Ekstrak sampel yang mengandung antioksidan diambil sebanyak $1 \mathrm{~mL}$ kemudian $1 \mathrm{~mL}$ larutan DPPH yang telah disiapkan di dalam tabung reaksi bertutup dan dibungkus aluminium foil. Selanjutnya dinyalakan stop watch. Campuran tersebut kemudian dipisahkan endapan dan filtratnya menggunakan alat vortex dan disimpan tabung reaksi di tempat yang gelap. Setelah stop watch menunjukkan waktu 30 menit, segera ditentukan absorbansi sampel dengan menggunakan spektrofotometer pada panjang gelombang $517 \mathrm{~nm}$. Ditentukan juga absorbansi blanko. Blanko adalah $1 \mathrm{~mL}$ etanol yang dicampur dengan $1 \mathrm{~mL}$ larutan DPPH dan diberi perlakuan sama dengan sampel. Aktivitas antioksidan dihitung dengan rumus pada persamaan (1).

$\%$ Aktivitas Antioksidan $=($ Absorbansi blanko - Absorbansi sampel $) \times 100 \% \ldots \ldots \ldots . \quad$ persamaan(1)

Absorbansi blanko

\section{c. Metode FRAP (Ferric Reducing Antioxidant Power) (Febriyanti et al, 2018).}

Untuk menentukan panjang gelombang maksimum standar asam askorbat di running pada panjang gelombang $650-750 \mathrm{~nm}$. Larutan standar asam askorbat $1000 \mathrm{ppm}$ di pipet sebanyak 0,4 ml kemudian ditempatkan pada labu ukur $10 \mathrm{ml}$ yang berbeda dan diencerkan dengan asam okslat $1 \%$ hingga batas $10 \mathrm{ml}$ dan dihomogenkan. Konsentrasi larutan standar asam askorbat $40 \mathrm{ppm}$ dipipet $1 \mathrm{ml}$ ke dalam tabung sentrifuge dicampur dengan buffer fosfat ( $1 \mathrm{~mL}, 0,2 \mathrm{M}, \mathrm{pH} 6,6)$ dan $1 \mathrm{~mL}$ kalium ferisianida $1 \%$, campuran diinkubasi pada suhu $5^{\circ} \mathrm{C}$ selama 20 menit. Setelah selesai diinkubasi, ditambahkan $1 \mathrm{~mL}$ asam trikloroasetat dan dihomogenkan selama 10 menit, selanjutnya disentrifuge pada 3000 rpm selama 10 menit. Diambil lapisan atas dari larutan tersebut sebanyak $1 \mathrm{ml}$ kemudian ditambahkan dengan $1 \mathrm{~mL}$ aquades dan $0,5 \mathrm{~mL} \mathrm{FeCl} 30,1 \%$. Absorbansi diukur pada absorbansi maks 650- 750 dengan spektro UV-Vis.

\section{Kadar Total Polifenol Dari Berbagai Buah-Buahan}

Polifenol adalah salah satu kategori terbesar dari fitokimia yang paling banyak penyebarannya diantara kingdom tanaman. Tanaman yang digunakan sebagai makanan kaya akan zat polifenol. Senyawa polifenol dikenal sebagai antioksidan alami karena menghasilkan aktivitas antioksidan, berperan sebagai agen pereduksi dan antioksidan pendonor atom hidrogen. Polifenol dapat menghambat, mencegah, mengurangi oksidasi oleh radikal bebas sehingga baik untuk kesehatan (Nely, 2000). 
Berdasarkan data yang diperoleh pada Tabel 1 dapat dilihat bahwa setiap bahan pangan atau buahbuahan memiliki kadar polifenol yang berbeda dengan berbagai pelarut dan konsentrasi sampel yang berbeda beda hal ini menunjukan bahwa setiap bahan alam yang diekstrak menggunakan pelarut yang berbeda belum bisa di bandingkan satu sama lain.

Tabel 1. Hasil analisis total kadar polifenol dari berbagai ekstrak buah-buahan

\begin{tabular}{|c|c|c|c|c|c|}
\hline No & Sampel & $\begin{array}{l}\text { Jenis } \\
\text { Pelarut }\end{array}$ & $\begin{array}{l}\text { Kadar } \\
\text { Polifenol }\end{array}$ & Rendemen & Sumber \\
\hline 1 & $\begin{array}{l}\text { Ekstrak buah bisbul matang (Diospyros } \\
\text { blancoi A. DC.) }\end{array}$ & Etanol & $25,09 \%$ & $53,34 \%$ & $\begin{array}{l}\text { Sukmana et al., } \\
2017\end{array}$ \\
\hline 2 & $\begin{array}{l}\text { Ektrak buah papaya California (Carica } \\
\text { papaya L.) }\end{array}$ & Etanol & $0,09 \%$ & $1,55 \%$ & $\begin{array}{l}\text { Farissi et al., } \\
2010\end{array}$ \\
\hline 3 & Ekstrak buah murbei (Morus alba L.) & Etanol & $8,047 \%$ & $10,2 \%$ & $\begin{array}{l}\text { Hilwiyah et al., } \\
2012\end{array}$ \\
\hline 4 & $\begin{array}{l}\text { Ekstrak buah anggur merah (Vitis vinifera } \\
\text { Linn. Var. Red Globe) }\end{array}$ & Etanol & $1,49 \%$ & $2,05 \%$ & Yanita, 2011 \\
\hline 5 & $\begin{array}{l}\text { Ekstrak buah anggur hijau (Vitis vinifera } \\
\text { Linn. Var. Chinsiang) }\end{array}$ & Etanol & $0,21 \%$ & $1,85 \%$ & Yanita, 2011 \\
\hline 6 & Ekstrak buah delima (Punica granatum L.) & Metanol & $23,1 \%$ & $36,2 \%$ & Apriliana, 2010 \\
\hline 7 & $\begin{array}{l}\text { Ekstrak buah Alpukat (Persea Americana } \\
\text { MILL.) }\end{array}$ & Etanol & $5,09 \%$ & $5,72 \%$ & $\begin{array}{l}\text { Febrianti dan } \\
\text { Zulfikar, } 2016\end{array}$ \\
\hline 8 & $\begin{array}{l}\text { Ekstrak buah patikala (Etlingera elatior } \\
\text { (Jack) R.M.SM) }\end{array}$ & Metanol & $0.22 \%$ & $1,92 \%$ & $\begin{array}{l}\text { Ahmad et al., } \\
2015\end{array}$ \\
\hline 9 & $\begin{array}{l}\text { Ekstrak buah pisang goroho (Musa sapien } \\
\text { sp.) }\end{array}$ & $\begin{array}{l}\text { Etanol } \\
\text { Metanol } \\
\text { Aseton }\end{array}$ & $\begin{array}{l}1,52 \% \\
1,62 \% \\
1,81 \%\end{array}$ & $\begin{array}{l}2,67 \% \\
2,70 \% \\
3,05 \%\end{array}$ & $\begin{array}{l}\text { Suryanto et al., } \\
2011\end{array}$ \\
\hline 10 & $\begin{array}{l}\text { Ekstrak buah bidara (Ziziphus spina-christi } \\
\text { I.) }\end{array}$ & Etanol & $5,11 \%$ & $5,76 \%$ & $\begin{array}{l}\text { Kusriani et al., } \\
2015\end{array}$ \\
\hline
\end{tabular}

Pada Tabel 1 dapat dilihat bahwa buah-buahan yang memilki kadar polifenol tertinggi yaitu pada buah bisbul yang di ekstrak menggunakan pelarut etanol sebesar 25,09\%. Selanjutnya, pada ekstrak buah delima yang di ekstrak menggunakan pelarut metanol yang memilki kadar polifenol sebesar 23,1\%. Sedangkan pada buahbuahan lain juga memiliki kadar polifenol namun mempunyai perbandingan yang cukup jauh yaitu seperti pada ekstrak buah pepaya California 0,09 \%, ekstrak buah anggur hijau 0,21\%, dan ekstrak buah patikala 0,22 \%. Perbedaan rendemen polifenol ini dapat terjadi karena dipengaruhi oleh beberapa faktor, yang pertama adalah spesies sampel karena masing-masing sampel memiliki keragaman genetik yang berbeda-beda sehingga 
memungkinkan sampel menunjukkan nilai rendemen senyawa aktif yang berbeda-beda (Andersen \& Markham 2006). Faktor yang kedua adalah besar kecilnya luas permukaan sampel, menurut Partang (2008) luas permukaan akan mempengaruhi proses ekstraksi, ukuran partikel yang baik dalam proses ekstraksi adalah kurang lebih 100-200 mesh. Faktor yang ketiga adalah pelarut dan metode yang digunakan untuk ekstraksi (Goli et al. 2004).

Sedangkang pada ekstrak buah pisang goroho di ekstrak menggunakan 3 pelarut yaitu etanol, metanoll dan aseton. Pada pelarut aseton menghasilkan kadar polifenol yang cukup tinggi yaitu 1,81 \%, dibandingkan menggunakan pelarut etanol dan metano yaitu $1,62 \%$ dan 1,52 \%. Tinggi rendahnya kandungan total fenolik dalam ekstrak buah pisang goroho berhubungan langsung dengan aktivitas penangkal radikal bebas dari masing masing pelarut yang digunakan pada ekstrak pisang goroho.

\section{Aktivitas Antioksidan dari Berbagai Buah-Buahan}

Aktivitas antioksidan alami yang diperoleh dari beragam sumber bahan pangan, seperti buah-buahan memiliki kandungan antioksidan yang berbeda-beda. Antioksidan tersebut merupakan senyawa pemberi elektron (electron donor) atau reduktan. Senyawa ini memiliki berat molekul yang berbeda-beda dengan ukuran yang sangat kecil, tetapi mampu menginaktivasi berkembangnya reaksi oksidasi, dengan cara mencegah terbentuknya radikal. Antioksidan juga merupakan senyawa yang dapat menghambat reaksi oksidasi, dengan mengikat radikal bebas dan molekul yang sangat reaktif (Winarsi, 2007).

Hasil analisis aktivitas antioksidan dari berbagai buah-buahan dapat dilihat pada Tabel 2.

Tabel 2. Hasil aktivitas antioksidan dari berbagai buah-buahan

\begin{tabular}{|c|c|c|c|c|c|}
\hline & Sampel & Jenis Pelarut & $\begin{array}{c}\text { Aktivitas } \\
\text { Antioksidan }\end{array}$ & Metode & Sumber \\
\hline 1 & $\begin{array}{l}\text { Ekstrak buah naga Merah (Hylocereus } \\
\text { polyrhizus (f.a.c weber) britton \& rose) }\end{array}$ & Metanol & $96,99 \%$ & DPPH & $\begin{array}{l}\text { Umayah dan } \\
\text { Amrun, } 2007\end{array}$ \\
\hline 2 & $\begin{array}{l}\text { Ekstrak Buah Semangka (Citrullus } \\
\text { lanatus) }\end{array}$ & Etanol & $0,13 \%$ & FRAP & $\begin{array}{l}\text { Masdiana et al., } \\
2016\end{array}$ \\
\hline 3 & $\begin{array}{l}\text { Ekstrak Etanol Secang (Caesalpinia } \\
\text { sappan L.) }\end{array}$ & Etanol & $27,98 \%$ & FRAP & $\begin{array}{l}\text { Febriyanti et a., } \\
2018\end{array}$ \\
\hline 4 & $\begin{array}{l}\text { Ekstrak fenolik buah papaya (Carica } \\
\text { papaya) }\end{array}$ & Etanol & $78,9 \%$ & DPPH & $\begin{array}{l}\text { Christalina et al, } \\
2016\end{array}$ \\
\hline 5 & $\begin{array}{l}\text { Ekstrak biji buah durian (Durio zibethinus } \\
\text { murr) }\end{array}$ & Etanol & $94,40 \%$ & DPPH & $\begin{array}{l}\text { Amir dan Saleh, } \\
2014\end{array}$ \\
\hline 6 & $\begin{array}{l}\text { Ekstrak buah bidara (Ziziphus spina- } \\
\text { christi l.) }\end{array}$ & Etanol & $31,5 \%$ & DPPH & $\begin{array}{l}\text { Kusriani et al., } \\
2015\end{array}$ \\
\hline
\end{tabular}


$7 \quad$ Ekstrak buah nipah (Nypa fruticans)

Metanol

$22,91 \%$

DPPH

Putri et al., 2012

Ekstrak etanol buah buni (Antidema

Etanol

$20,49 \%$

DPPH

Wijayanti, 2016 thwaitesianum)

Hasil pada Tabel 2 buah yang memiliki kandungan antioksidan tertinggi yaitu pada ekstrak buah naga sebesar 96,99 \% yang di ekstrak menggunakan pelarut metanol. Tingginya aktivitas antioksidan buah naga merah karena memiliki kandungan vitamin $\mathrm{C}$ dan karoten yang bersifat antioksidan. Ekstrak biji buah durian yang di ekstrak menggunaka pelarut metanol mempunyai kandungan antioksidan sebesar 94,40\%. Sedangkan kandungan antioksidan yang terendah yaitu pada ekstrak buah semangka dengan kandungan antioksidan sebesar 0,1329 \% dengan menggunaka metode FRAP (Ferric Reducing Antioxidant Power).

Aktivitas antioksidan pada berbagai pelarut menunjukan bahwa total flavonoid memiliki korelasi positif dengan aktivitas antioksidan. Dapat dilihat pada ekstrak buah naga menggunakan pelarut metanol memiliki aktivitas antioksidan lebih tinggi dibandingkan dengan pelarut etanol. Hal ini disebabkan karena suatu senyawa akan larut baik pada pelarut yang mempunyai kepolaran yang sama (Kemit et al, 2015).

\section{KESIMPULAN}

Senyawa polifenol terdapat diberbagai buah-buahan. Proses analisis kadar polifenol dapat dilakukan dengan cara diekstraksi dan dapat menggunakan berbagai pelarut. Hasil analisis kadar polifenol yang terdapat pada buah-buahan menunjukan bahwa setiap bahan alam yang diekstrak menggunakan pelarut yang berbeda belum bisa dibandingkan satu sama lain. Buah-buahan yang memilki kadar polifenol tertinggi yaitu pada buah bisbul yang di ekstrak menggunakan pelarut etanol sebesar 25,09 \% dan pada ekstrak buah delima yang di ekstrak menggunakan pelarut metanol yang memilki kadar polifenol sebesar $23,1 \%$. Sedangkan pada antivitas antioksidan, ekstrak buah naga memiliki aktivitas tertinggi dan aktivitas antioksidan terendah dimiliki oleh sampel ekstrak buah Semangka dibandingkan sampel lainnya dalam review ini.

\section{DAFTAR PUSTAKA}

Ahmad, A.R., Juwita. dan Ratulangi, S.A.D. 2015. Penetapan Kadar Fenolik dan Flavonoid Total Ekstrak Metanol Buah dan Daun Patikala (Etlingera elatior (Jack) R.M.SM). Pharm Sci Res 2(1): 1-10

Amir, F., dan Saleh, C. 2014. Uji aktivitas antioksidan ekstrak etanol biji buah durian(duriozibethinus murr) dengan menggunakan metode DPPH. Jurnal Kimia Mulawarman. 11 (2) :84-87

Andersen, M., and Markham, K.R. 2006. Flavonoids Chemistry, Biochemistry and Applications. CRC Pr. Boca 
Raton

Apriliani, D. 2010. Aktivitas Hepatoproteksi Ekstrak Polifenol Buah Delima (Punica granatum L.) Terhadap Tikus Putih Yang Diinduksi Parasetamol. Skripsi. Departemen Biokimia Fakultas Matematika Dan IImu Pengetahuan Alam Institut Pertanian Bogor. Bogor

Arifulloh, Oktavianawati, I., dan Winata. 2016. Ekstraksi Likopen dari Buah Tomat (Lycopersicum esculentum mill) Dengan Berbagai Komposisi Pelarut. Berkala Sainstek. 4(1):15-18

Baradaran, A., Nasri, H., dan Kopaei, R.M. 2014. Oxidative Stress and Hypertension. Possibility of Hypertension Therapy with Antioxidants. Journal of research in medical sciences. 19(4):358-367

Chin, E., Miller, K.B., Payne, W.J., Hurst, M.J., Stuart, D.A. 2013. Comparison of Antioxidant Activity and Flavanol Content of Cocoa Beans Processed by Modern and Traditional Mesoamerican Methods. Heritage Science. 1(9): 1-7

Christalina, I.T.E., Susanto, Ayucitra, A., Setiyadi. 2016. Aktivitas antioksidan dan antibakteri alami Ekstrak fenolik biji pepaya. Jurnal IImiah. 6 (5) :18-25

Dhianawaty, D., dan Panigoro, R. 2013. Antioxidant Activity of The Waste Water of Boiled Zea Mays (swett corn) on The Cob. Int J Res Pharm Sci. 4(2):266-9

Farissi, R., Wardatun, S., dan Miranti, M. 2010. Penentuan Flavonoid, Polifenol, Kapasitas Antioksidan Ekstrak Buah dan Sari Buah Pepaya California. Program Studi Farmasi. Fakultas Matematika dan IImu Pengetahuan Alam. Universitas Pakuan. Bogor

Febrianti, N., dan Zulfikar, M. 2016. Aktivitas Antioksidan Buah Alpukat (Persea Americana Mill.) dan Buah Stroberi (Fragaria Vesca L.). Prosiding Symbion. 8(6): 2528-5726

Febriyanti, Suharti N, Lucida H, Husni E, dan Sedona O. 2018. Karakterisasi dan Studi Aktivitas Antioksidan dari Ekstrak Etanol Secang (Caesalpinia sappan L.). Jurnal Sains Farmasi \& Klinis. 5(1) : 23-27

Febriyanti., Suharti, N., Lucida, H., Husni, E., Sedona, O. 2018. Karakterisasi dan Studi Aktivitas Antioksidan dari Ekstrak Etanol Secang (Caesalpinia sappan L.). Jurnal Sains Farmasi \& Klinis. 5(1) : 23-27

Goli, A.H., Baregar, M., Sahari, M.A. 2004. Antioxidant activity and total phenolic compounds of pistachio (Pistachia vera) hull extract. Food Chem. 92 (1): 521-525

Gu, L., House, S.E., Wu, X., Ou, B., Prior, R.L. 2006. Procyanidin and Catechin Contents and Antioxidant Capacity of Cocoa and Chocolate Products. Journal of Agricultural and Food Chemistry. 54(11): 40574061 
Hilwiyah, A., Lukiati B., dan Nugrahaningsih. 2012. Skrining Fitokimia dan Uji Aktivitas Antioksidan serta Kadar Total Fenol Flavonoid Ekstrak Etanol Murbei (Morus alba L.). Program Studi Biologi. Fakultas Matematika dan IImu Pengetahuan Alam. Universitas Negeri Malang. Malang

Huang, D., Ou, B., dan Prior, R.L. 2005. The Chemistry Behind Antioxidant Capacity Assays. Journal of Agricultural and Food Chemistry. 53(6): 1841-1856

Kemit, N., Widarta, I.W.R., dan Nocianitri, K.A. 2015. Pengaruh jenis pelarut dan waktu maserasi terhadap Kandungan senyawa flavonoid dan aktivitas Antioksidan ekstrak daun alpukat (Persea americana mill). Jurnal IImiah.5 (3) :130-141

Kuncahyo, I., dan Sunardi. 2007. Uji Aktivitas Antioksidan Ekstrak Blimbing Wuluh (Averrhoa blimbi, L) Terhadap 1,1-diphenyl-2-picrylhidrazil (DPPH). Prosiding Seminar Nasional Teknologi. Yogyakarta. 19(78): $97-99$

Kusriani, R.H., Nawawi, A., dan Machter, E. 2015. Penetapan Kadar Senyawa Fenolat Total dan Aktivitas Antioksidan Ekstrak Daun, Buah dan Biji Bidara (Ziziphus Spina-Christi L.). Prosiding kesehatan. 7(6): 2477-2356

Marinova, G., dan Batcharov, V. 2011. Evalution The Method Determination of The Free Radical Scavenging Activity By DPPH. Jurnal of Agricurtural Science. 17(1): 11-24

Masdiana, T., Anda, Ca., dan Harti, W. 2016. Uji Aktivitas Antioksidan Buah Semangka (Citrullus lanatus) dengan metode FRAP. Jurnal As Syifa. 8 (1) :54-61

Mensah, M.E.E., Komlaga, G., dan Terlabi, E.O. 2010. Antiypertensive Action of Ethanolic Extract of Imperata Cylindrica Leaves in Animal Models. L Med Plants Resch. 4(14):1486-91

Miller, K.B., Stuart, D.A., Smith, N.L., Lee, C.Y., McHale, N.L., Flanagan, J.A., Ou, B., Hurst, W.J. 2006. Antioxidant Activity and Polyphenols and Procyanidin Contents of Selected Commercially Available Cocoa Containing and Chocolate Product in The United States. Journal of Agricultural and Food Chemistry. 54 (11): 4062-4068

Nely F. 2002. Aktivitas Antioksidan Rempah Pasar dan Bubuk Rempah Pabrik Dengan Metode Polifenol dan Uji AOM (Active Oxygen Method). Skripsi. Fakultas Teknologi Pertanian. Institut Pertanian Bogor. Bogor.

Partang, M.A. 2008. Analisis dan Teknik Sampling Dalam Kimia Analitik. UPI Pr. Bandung

Putri, I.J., Fauziah, dan Elfita. 2012. Aktivitas Antioksidan Daun dan Biji Buah Nipah (Nypa fruticans) Asal Pesisir Banyuasin Sumatera Selatan Dengan Metode DPPH. Maspari Journal. 5(1): 16-21

Redovnikovic, I.R., Delonga, K., Mazor, S., Dragovic V., Caric, M., Vorkapic, J. 2009. Polyphenolic Content and 4482 | P a g e 
Composition and Antioxidative Activity of Different Cocoa Liquors. Czech Journal of Food Sciences. 27(5): 330-337

Shimamura, T., Sumikura, Y., Yamazaki, T., Tada, A., Kashiwagi, T., Ishikawa, H., Matsui, T., Sugimoto, N., Akiyama, H., Ukeda, H. 2014. Applicability of the DPPH Assay for Evaluating the Antioxidant Capacity of Food Additives Inter laboratory Evaluation Study. Analytical Sciences. 30(7): 717-721

Sukmana, I.K., Lukmayani, Y., dan Kodir R.A. 2017. Penetapan Kadar Flavonoid Total dan Polifenol Total dari Ekstrak Etanol Buah Bisbul (Dipyros blancoi A. DC.) dengan Perbedaan Kematangan. Prosiding Farmasi. 3(2): 2460-6472

Supriyanto,T, dan Wahyudi. 2010. Proses Produksi Etanol Oleh Saccharomyces Cerivisiae Dengan Operasi Kontinyu Pada Kondisi Vakum. Teknik Kimia. Universitas Diponogoro. Semarang

Suryanto, E., Momuat, L.I., Taroreh, M., Wehantouw, F. 2011. Potensi Senyawa Polifenol Antioksidan dari Pisang Goroho (Musa sapien Sp). Fakultas Pertanian Universitas Sam Ratulangi. Manado

Umayah, E., dan Amrun, M.H. 2007. Uji Aktivitas Antioksidan Ekstrak Buah Naga (Hylocereus undatus (Haw.) Britt. \& Rose). Jurnal Ilmu Dasar. 8 (1) : 83-90

Wade, L.G. 2006. Organic Chemistry. Sixth edition. Pearson Education International. New Jersey

Wijayanti, N.M. 2016. Uji Anktivitas Antioksidan dan Penetapan Kadar Fenolik Total Ekstrak Etanol Buah Buni Dengan Metode DPPH dan Metode Folinciocealtau. Skripsi. Fakultas Farmasi Universitas Sanata Dharma. Yokyakarta

Winarsi H. 2007. Antioksidan Alami dan Radikal Bebas Potensi dan Aplikasi dalam Kesehatan. Kanisius. 15 (2) :101-106

Yuan, J., Wang, L., dan Wang, Y. 2011. Direct Oxidation of Methane to a Methanol Derivative Using Molecular Oxygen. Journal Of Catalysis. 50(10): 6513-6516

Yunita. 2011. Penentuan Aktivitas Antioksidan Dan Kadar Senyawa Fenolat Total Pada Buah Anggur Merah (Vitis Vinifera Linn. Var. Red Globe) Dan Anggur Hijau (Vitis Vinifera Linn. Var. Chinsiang). Skripsi. Fakultas Farmasi. Universitas Andalas. Padang 